\title{
Kemudahan Biodegradasi Selulosa Bakteri dari Limbah Cucian Beras dengan Penambahan Gliserol, Kitosan, dan Nanopartikel Perak
}

\author{
Eli Rohaeti, Endang Widjajanti LFX, Anna Rakhmawati
}

Prodi Kimia Fakultas Matematika dan Ilmu Pengetahuan Alam, Universitas Negeri Yogyakarta

Email: rohaetieli64@gmail.com

Received: April 2016; Revised: Mei 2016; Accepted: Mei 2016; Available Online: Mei 2016

\begin{abstract}
Abstrak
Penelitian ini bertujuan mempelajari pengaruh penambahan gliserol dan kitosan terhadap kemudahan biodegradasi selulosa dari limbah air cucian beras, pengaruh lama biodegradasi terhadap kehilangan massa dan laju kehilangan massa, serta gugus fungsi dan kristalinitas selulosa yang paling mudah dibiodegradasi. Selulosa bakteri dipreparasi dari $100 \mathrm{~mL}$ air cucian beras yang difermentasi oleh bakteri Acetobacter xylinum selama 7 hari. Selulosa-Gliserol dan Selulosa-Gliserol-Kitosan dipreparasi dengan penambahan gliserol. Selulosa-Kitosan dan Selulosa-Gliserol-Kitosan dipreparasi melalui perendaman dalam larutan kitosan. Selulosa dan kompositnya dikeringkan kemudian dideposit dengan nanopartikel perak yang dihasilkan secara reduksi kimia dari larutan perak nitrat, gelatin sebagai penstabil, dan natrium sitrat sebagai pereduksi. Selulosa dan kompositnya selanjutnya dibiodegradasi dengan metode soil burrial test selama 14 hari. Selanjutnya selulosa yang paling mudah dibiodegradasi dikarakterisasi gugus fungsi dengan ATR-FTIR, kristalinitas dengan XRD, serta kehilangan massa dan laju kehilangan massa dengan teknik gravimetri. Terbentuknya koloid nanopartikel perak ditunjukkan oleh spektrum UV-Vis dengan puncak serapan di daerah 418,8 nm. Penambahan gliserol dapat meningkatkan kemudahan biodegradasi selulosa, sedangkan penambahan kitosan dapat menurunkan kemudahan biodegradasi selulosa. Semakin lama biodegradasi, kehilangan massa semakin meningkat sedangkan laju kehilangan massa semakin menurun. Sesudah biodegradasi, Selulosa-Gliserol dideposit nanopartikel perak (SG $+\mathrm{Ag}$ ) mengalami penurunan intensitas siklik piran dan peningkatan kristalinitas.
\end{abstract}

Kata kunci : Biodegradasi, gliserol, kitosan, nanopartikel perak, selulosa bakteri.

\begin{abstract}
The objectives of this research were to study the effect of glycerol and chitosan addition toward biodegradability of cellulose based rice waste water, the effect of biodegradation time toward mass lost and biodegradability, and determine functional group and crystalinity of the highest biodegradability composite. Bacterial celluloses were prepared from $100 \mathrm{~mL}$ rice waste water that fermented by Acetobacter xylinum for 7 days with addition of glycerol (for Cellulose-Glycerol and Cellulose-Glycerol-Chitosan). Then, bacterial celluloses were immersed in chitosan solution (for Cellulose-Chitosan and Cellulose-Glycerol-Chitosan). The water in bacterial cellulose and its composites was removed by heating, then deposited silver nanoparticle on the bacterial cellulose and its composite. The silver nanoparticles were prepared by chemical reduction with using $\mathrm{AgNO}_{3}$ solution, trisodium citric as reducing agent, and gelatin as stabilizer. The silver nanoparticle was deposited into bacterial cellulose and its composites film by immersing method. After that, the bacterial cellulose and its composites were biodegradated by soil burrial test method for 14 days. Then, cellulose with the highest biodegradability was characterized by ATR-FTIR and XRD. The silver nanoparticle formation was showed by UV-Vis spectrum with peak in the $418.8 \mathrm{~nm}$ area. The glycerol addition can increase biodegradability, whereas the chitosan addition can decrease biodegradability. The increasing of biodegradation time, mass lost increased but the biodegradability decreased. After biodegradation, intensity of pyran cyclic in cellulose-glycerol which is deposited Ag $(\mathrm{SG}+\mathrm{Ag})$ decreased, but crystallinity of it increased.
\end{abstract}

Keywords : Biodegradation, glycerol, chitosan, silver nanoparticle, bacterial cellulose.

DOI: http://dx.doi.org/10.15408/jkv.v2i1.3111 


\section{PENDAHULUAN}

Indonesia merupakan negara dengan tingkat konsumsi beras sangat tinggi di dunia mencapai 130 kilogram per kapita per tahun atau lebih dari 2 kali lipat konsumsi rata-rata dunia yang hanya 60 kilogram per kapita per tahun (Susakti, 2014). Biasanya, air limbah cucian beras yang dihasilkan ketika membersihkan beras dibuang begitu saja. Air cucian beras sebenarnya tidak membahayakan untuk kesehatan, akan tetapi dapat mencemari air bersih. Saat ini, limbah air cucian beras belum dimanfaatkan secara optimal. Padahal, air cucian beras mengandung karbohidrat cukup tinggi berasal dari kulit ari beras yang terkelupas.

Limbah rumah tangga seperti air cucian beras mengandung sumber karbon yang dapat dijadikan bahan untuk pembuatan polimer selulosa (Rohaeti dan Pratomo, 2011). Air cucian beras memenuhi syarat untuk pertumbuhan bakteri Acetobacter xylinum karena masih mengandung gula karbohidrat berupa pati (85-90\%), protein glutein, selulosa, hemiselulosa, gula, dan vitamin yang tinggi (Handiyanto et al., 2002).

Selulosa yang berasal dari limbah air cucian beras dan difermentasi oleh bakteri Acetobacter xylinum disebut selulosa bakteri. Selulosa bakteri tidak seperti selulosa pada tumbuhan, memiliki kemurnian tinggi, kerapatan 300-900 kg/m ${ }^{3}$, kekuatan tarik tinggi, elastis, struktur jaringan selulosa bakteri terdiri dari nanofibril dengan diameter 3-8 nm, dan terbiodegradasi (Bielecki, 2002; Chawla et al., 2009). Selulosa bakteri memiliki sifat seperti hidrogel yang diperoleh dari polimer sintetik, memiliki kadar air yang tinggi (98$99 \%$ ), daya serap cairan yang baik, bersifat non-alergenik, dan dapat disterilisasi tanpa mempengaruhi karakteristik bahan. Selulosa memiliki karakteristik yang mirip dengan kulit manusia, sehingga dapat digunakan untuk penanganan luka bakar yang serius (Torres $e t$ al., 2012). Serat yang terbentuk dalam selulosa bakteri 100 kali lebih tipis daripada selulosa tumbuhan. Hal ini menyebabkan material ini mudah menyerap air sehingga dapat digunakan sebagai penyalur antibiotik ataupun obatobatan ke dalam luka ketika terjadi luka luar (Zhang dan Luo, 2011). Oleh sebab itu, material ini dapat digunakan sebagai penyembuh luka.

Syarat utama bahan yang dapat digunakan sebagai penutup luka adalah bersifat elastis, antibakteri, dan biokompatibel. Gliserol dapat ditambahkan ke dalam selulosa untuk meningkatkan elastisitas dari selulosa tersebut (Chawla et al., 2009; Whardani et al., 2014). Penambahan gliserol $2 \%$ ke dalam selulosa bakteri dapat menurunkan tensile strength dan meningkatkan strain selulosa (Rohaeti dan Rahayu, 2012). Selulosa bakteri bersifat higroskopis (mudah menyerap air), sehingga bakteri dapat dengan mudah masuk ke dalamnya. Penambahan kitosan dapat dilakukan untuk mengurangi sifat higroskopis selulosa. Menurut Sanjaya dan Puspita (2010), penambahan kitosan 2\% menyebabkan swelling semakin kecil atau proses penyerapan air semakin menurun. Dengan demikian kitosan dapat meningkatkan ketahanan selulosa terhadap air. Hal ini terjadi karena kitosan bersifat hidrofobik dan sulit larut dalam air.

Menurut Torres et al., (2011) kompatibel adalah kemampuan suatu material yang menunjukkan ketepatan fungsinya dalam aplikasi tertentu. Kompatibel selulosa bakteri sebagai wounddressing berhubungan dengan kekhasan struktur nanofibril yang dimilikinya. Struktur ini menghilangkan gejala nyeri dan meningkatkan proses penyembuhan luka. Kebanyakan material biomedis ini harus didatangkan dari luar negeri dan sulit terdegradasi. Namun demikian, saat ini sedang dikembangkan material yang dapat terbiodegradasi sebagai upaya untuk mengurangi impor bahan kain untuk keperluan medis, mengurangi pencemaran limbah plastik/polimer, dan diversifikasi produk untuk meningkatkan nilai guna suatu bahan olahan limbah.

Menurut Mutia et al., (2011), pembalut luka terbagi menjadi produk tenun dan nonwoven. Produk non-woven dapat berupa lembaran, lapisan tipis/ membran, dan komposit. Produk non-woven ini dapat diperoleh dari selulosa bakteri. Aplikasi nanopartikel perak pada selulosa bakteri atau kompositnya dilakukan untuk meningkatkan aktivitas antibakteri selulosa.

Material dengan struktur nano (1-100 $\mathrm{nm})$ saat ini sedang dikembangkan sebagai antibakteri. Material-material yang memiliki fungsi antibakteri antara lain adalah tembaga, seng, titanium, magnesium dan emas, alginat, serta perak. Material perak banyak digunakan karena merupakan bahan dengan konduktivitas baik, stabil secara kimiawi, dapat berfungsi sebagai katalis, memiliki aktivitas sebagai 
antibakteri, serta tidak bersifat toksik terhadap sel manusia (Saputra et al., 2012). Selulosa dari limbah air cucian beras yang terdeposit nanopartikel perak positif memiliki aktivitas antibakteri (Senam et al., 2012; Flieger et al., 2003).

Nanopartikel perak mengalami aglomerasi ketika proses preparasi. Bahan penstabil perlu ditambahkan agar tidak terjadi aglomerasi. Bahan yang dapat digunakan sebagai penstabil adalah asam lemak rantai panjang (asam stearat, palmitat, dan laurat), polivinil pirolidon, soluble starch, dan gelatin (Christy dan Umadevi, 2012).

Salah satu syarat yang harus dipenuhi oleh suatu wounddressing adalah mudah terbiodegradasi. Kemudahan material terdegradasi dapat diketahui melalui uji biodegradasi. Proses biodegradasi terhadap material organik dapat dilihat dari fakta dalam siklus makanan di alam material yang ada akan berkurang jumlahnya. Metode biodegradasi dapat dilakukan di lingkungan yang sesungguhnya, yaitu dipendam dalam tanah atau dengan metode simulasi (Rohaeti, 2009). Metode simulasi dapat dilakukan dengan menggunakan mikroorganisme campuran atau dengan mikroorganisme tertentu yang telah diketahui jenisnya.

Tulisan ini akan membahas preparasi dan karakterisasi selulosa bakteri dari limbah air cucian beras dan kompositnya. Karakterisasi yang dilakukan meliputi kemudahan biodegradasi (kehilangan massa dan laju kehilangan massa), gugus fungsi, dan kristalinitas. Kemudahan biodegradasi selulosa dan kompositnya dilakukan dengan metode soil burrial test.

\section{METODE PENELITIAN}

\section{Alat dan Bahan Penelitian}

Alat-alat yang digunakan dalam penelitian ini meliputi spektrometer UV-Vis Shimadzu UV-2400 PC Series, ATR-FTIR Frontier S/N 96772, XRD Rigaku MiniFlex600, neraca analitik, keranjang plastik, beakerglass, labu takar, botol flakon, nampan plastik, panci, kompor, pinset, set peralatan refluks, magnetic stirrer, Erlenmeyer, desikator, loyang, gelas arloji, tabung reaksi, gelas ukur, pipet tetes, pengaduk, dan spatula.

Bahan-bahan yang digunakan dalam penelitian ini meliputi limbah air cucian beras, gliserol, kitosan, akuades, air, koran bekas,
$\mathrm{NaOH}, \mathrm{CH}_{3} \mathrm{COOH}$, gula pasir, urea, bakteri Acetobacter xylinum yang diperoleh dari PT. Chemix Yogyakarta, natrium sitrat, alkohol $70 \%$, gelatin, $\mathrm{AgNO}_{3}$, karet, kain kasa, dan tanah.

\section{Pembuatan Selulosa, Selulosa-Gliserol, Selulosa-Kitosan, dan Selulosa-Gliserol- Kitosan}

Selulosa bakteri (SB) dibuat dengan cara menyiapkan terlebih dahulu limbah air cucian beras. Sebanyak $0.5 \mathrm{~kg}$ beras IR64 dicuci dengan $500 \mathrm{~mL}$ air. Selanjutnya ke dalam 100 $\mathrm{mL}$ air cucian beras ditambahkan 10 gram gula pasir dan 0.5 gram urea, diaduk hingga larut. $\mathrm{CH}_{3} \mathrm{COOH} 24 \%$ ditambahkan ke dalam campuran hingga $\mathrm{pH}$ menjadi 4 sambil dipanaskan. Campuran dituangkan ke dalam wadah fermentasi. Acetobacter xylinum sebanyak $20 \mathrm{~mL}$ ditambahkan ke dalam campuran. Campuran difermentasi hingga 7 hari pada suhu kamar. Lapisan pelikel yang terbentuk dicuci dengan akuades kemudian dikeringkan dengan cara dipanaskan dalam oven pada suhu $100{ }^{\circ} \mathrm{C}$.

Selulosa-Gliserol (SG) dibuat dengan cara menambahkan 10 gram gula pasir dan 0.5 gram urea ke dalam $100 \mathrm{~mL}$ air cucian beras. Selanjutnya dilakukan pengadukan hingga larut dan ditambahkan $\mathrm{CH}_{3} \mathrm{COOH} 24 \%$ ke dalam campuran hingga $\mathrm{pH}$ menjadi 4 sambil dipanaskan. Gliserol sebanyak 0.5 gram ditambahkan ke dalam campuran sambil dipanaskan hingga larut. Campuran dituangkan ke dalam wadah fermentasi. Acetobacter xylinum sebanyak $20 \mathrm{~mL}$ ditambahkan ke dalam campuran. Campuran difermentasi hingga 7 hari pada suhu kamar. Lapisan pelikel yang terbentuk dicuci dengan akuades kemudian dikeringkan di atas pemanas.

Selulosa-Kitosan (SK) dibuat dengan cara merendam lapisan pelikel selulosa bakteri (SB) dalam larutan kitosan 2\% dan mengeringkannya dalam oven pada suhu $50^{\circ} \mathrm{C}$ - Selulosa-Gliserol-Kitosan (SGK) dibuat dengan cara merendam lapisan pelikel Selulosa-Gliserol (SG) dalam larutan kitosan $2 \%$. Lapisan pelikel SG dalam larutan kitosan dikeringkan dalam oven pada suhu $50{ }^{\circ} \mathrm{C}$.

\section{Preparasi dan Karakterisasi Nanopartikel Perak}

Larutan perak nitrat $10^{-3} \mathrm{M}$ sebanyak $100 \mathrm{~mL}$ dimasukkan ke dalam labu leher tiga dan dicampur dengan gelatin 0.5 gram kemudian direfluks sampai suhu $90-100{ }^{0} \mathrm{C}$ 
sambil dilakukan pengadukan. Gas Nitrogen dialirkan selama refluks untuk mengusir oksigen. Natrium sitrat tetes demi tetes ditambahkan ke dalam larutan pada suhu sekitar $80-90^{\circ} \mathrm{C}$ sampai larutan berwarna kuning pucat. Pemanasan dihentikan dan pengadukan tetap dilakukan sampai mencapai suhu kamar. Larutan dikarakterisasi dengan UV-Vis.

\section{Aplikasi Nanopartikel Perak Terhadap Selulosa dan Kompositnya}

Sebanyak 1 lembar sampel selulosa bakteri dari air cucian beras dan kompositnya dipotong dengan ukuran $10 \times 10 \mathrm{~cm}^{2}$. Sampel dimasukkan ke dalam alkohol $70 \%$ selama 5 menit kemudian dikeringkan dalam desikator. Selanjutnya sampel dimasukkan ke dalam nanopartikel perak. Sampel selulosa bakteri dan kompositnya dimasukkan ke dalam koloid nanopartikel perak kemudian diaduk dengan shaker dengan kecepatan $145 \mathrm{rpm}$. Sampel selulosa bakteri dan kompositnya yang sudah dideposit nanopartikel perak ( $\mathrm{SB}+\mathrm{Ag}, \mathrm{SG}+\mathrm{Ag}$, $\mathrm{SK}+\mathrm{Ag}$, dan $\mathrm{SGK}+\mathrm{Ag}$ ) dikeringkan dan dikarakterisasi.

\section{Biodegradasi SB, SG, SK, dan SGK}

Tanah yang digunakan dalam uji biodegradasi antara lain mengandung bakteri Pseudomonas aeruginosa dan Streptomyces sp. (Tabel 1). Sampel dipotong berukuran $2 \times 3$ $\mathrm{cm}^{2}$ dan ditimbang bobotnya. Potongan sampel dibungkus dengan kain kasa agar tidak tercecer. Keranjang plastik diisi dengan tanah sebanyak setengah tinggi keranjang, lalu sampel diletakkan di atasnya, kemudian ditutup/ditimbun lagi dengan tanah. Sampel diamati dan ditimbang dalam rentang waktu 2 hari sekali selama 2 minggu.

Persen kehilangan massa sesungguhnya dapat dihitung dengan memasukkan faktor koreksi massa yang diperoleh dari kontrol negatif ke dalam massa sampel awal sebelum proses biodegradasi (Chulifah, 2010). Kontrol negatif adalah sampel selulosa yang dibiarkan selama waktu tertentu tanpa dilakukan penimbunan.

Massa sampel selulosa sesungguhnya sebelum mengalami proses biodegradasi dapat dihitung menggunakan persamaan 1 .

$\mathbf{W}_{\mathrm{i}}=\mathbf{W}_{\text {is }}-\left(\mathbf{W}_{\text {is }} \times \mathbf{C}\right)$

Keterangan :

$\mathrm{W}_{\mathrm{i}}=$ massa sampel sesungguhnya sebelum dibiodegradasi

$\mathrm{W}_{\text {is }}=$ massa sampel awal tanpa faktor koreksi massa

$\mathrm{C}=$ faktor koreksi massa

Faktor koreksi massa dihitung menggunakan persamaan 2.

$$
\mathbf{C}=\frac{w_{i c}-w_{f c}}{w_{i c}} \times 100 \%
$$

Keterangan:

$w_{i c}=$ massa sampel sebelum inkubasi (kontrol negatif)

$w_{f c}=$ massa sampel sesudah inkubasi (kontrol negatif)

Persen kehilangan massa sesungguhnya ditentukan dengan persamaan 3 .

Kehilangan massa $=\frac{w_{i}-w_{f}}{w_{i}} \times 100 \%$

Keterangan :

$w_{i}=$ massa sampel sebelum dibiodegradasi

$w_{f}=$ massa sampel sesudah dibiodegradasi

Laju kehilangan massa ditentukan dengan persamaan 4 .

$\mathbf{v}=\left(\mathbf{m}_{1}-\mathbf{m}_{2}\right) / \mathrm{t}$

Keterangan :

$\mathrm{v}=$ laju kehilangan massa ( $\mathrm{mg} /$ hari)

$\mathrm{m}_{1}=$ massa sampel sebelum biodegradasi $(\mathrm{g})$

$\mathrm{m}_{2}=$ massa sampel biodegradasi $(\mathrm{g})$

$\mathrm{t}=$ waktu inkubasi (hari)

Tabel 1. MIkroorganisme dalam tanah yang digunakan sebagai media biodegradasi

\begin{tabular}{cccc}
\hline Mikroorganis-me & Jumlah $(\mathbf{c f u} / \mathbf{g})$ & Metode Analisis & Media \\
\hline Pseudomonas aeruginosa & $1.5 \times 10^{5}$ & plating & King's B Agar \\
Streptomyces $s p$. & $1.0 \times 10^{4}$ & plating & Starch Nitrat Agar \\
\hline
\end{tabular}


Setelah diketahui sampel yang paling cepat terbiodegradasi berdasarkan perhitungan $\%$ kehilangan massa dan lajunya, selanjutnya sampel tersebut dikarakterisasi gugus fungsinya dengan ATR-FTIR dan kristalinitasnya dengan XRD.

\section{HASIL DAN PEMBAHASAN}

\section{Sifat Fisik Selulosa, Selulosa-Gliserol, Selulosa-Kitosan, dan Selulosa-Gliserol- Kitosan \\ Media air cucian beras mengandung} amilum ditunjukkan oleh uji kualitatif sehingga dapat berperan sebagai media untuk pertumbuhan bakteri Acetobacter xylinum. Penambahan gula pasir pada preparasi selulosa dan kompositnya berfungsi sebagai sumber karbon bagi bakteri untuk membentuk selulosa, sedangkan urea berfungsi sebagai sumber nitrogen yang dibutuhkan oleh mikroorganisme untuk tumbuh (Rohaeti, 2009).

Air cucian beras dan gula pasir dipanaskan, agar terhidrolisis menjadi maltosa. Maltosa dan sukrosa (gula pasir) berfungsi sebagai sumber karbon bagi bakteri. Faktor lingkungan seperti suhu, kelembaban udara, $\mathrm{pH}$, serta ketersediaan oksigen menentukan keberhasilan fermentasi. Penambahan gliserol dilakukan pada proses pembuatan SG dan SGK. Menurut (Rohaeti et al., 2014), selulosagliserol memilki tensile strength rendah, tetapi memiliki elongation tinggi daripada selulosa bakteri. Penurunan tensile strength dengan adanya penambahan gliserol ini dikarenakan adanya interaksi antara selulosa dengan gliserol yang menyebabkan polimer lebih plastis.

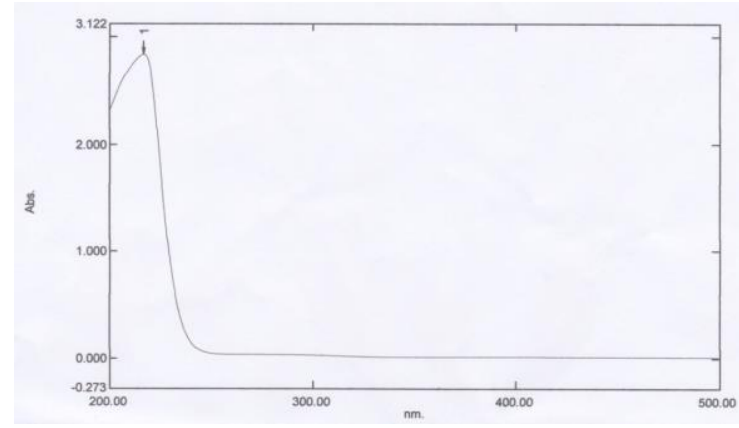

(a)
Penambahan kitosan dilakukan pada proses pembuatan selulosa-kitosan dan selulosa-gliserol-kitosan. Kitosan memiliki kemampuan untuk menghambat pertumbuhan bakteri (Tareq et al., 2013). Selulosa dengan penambahan kitosan memiliki tekstur lebih kaku. Sampel SB dan SG memiliki tekstur dan warna sama, yaitu halus pada permukaannya dan berwarna putih. Adanya penambahan gliserol tidak mempengaruhi kondisi tekstur permukaan dan warna pada film selulosa yang dihasilkan. SK dan SGK memiliki tekstur permukaan dan warna hampir sama, yaitu berwarna kuning kecoklatan dan bertekstur agak kasar. Dengan demikian, adanya pencelupan ke dalam kitosan berpengaruh terhadap warna dan tekstur film selulosa yang dihasilkan.

Film SB dan SG memiliki sifat lentur/plastis. Penambahan gliserol dapat meningkatkan plastisitas selulosa. Berbeda dengan SB dan SG, SK dan SGK bertekstur agak kaku. Kekakuan ini disebabkan karena adanya interaksi antara kitosan dengan selulosa membentuk ikatan hidrogen. Kitosan bersifat amorf sehingga film yang dihasilkan semakin rigid/kaku (Rohaeti et al., 2014).

\section{Karakteristik Nanopartikel Perak}

Refluks larutan perak nitrat $10^{-3} \mathrm{M}$ menghasilkan koloid nanopartikel perak ditunjukkan oleh adanya puncak serapan perak di daerah panjang gelombang $418.8 \mathrm{~nm}$ pada spektrum UV-Vis. Gelatin yang digunakan dalam preparasi nanopartikel perak berfungsi sebagai penstabil yang dapat mencegah terjadinya aglomerasi nanopartikel (Tareq et al., 2013). Gambar 1 menunjukkan spektrum UV-Vis larutan perak nitrat dan nanopartikel perak.



(b)

Gambar 1. (a). Spektrum UV-Vis larutan $\mathrm{AgNO}_{3} 10^{3} \mathrm{M}$; (b). nanopartikel perak 
Puncak di daerah panjang gelombang $418.8 \mathrm{~nm}$ menunjukkan bahwa telah terbentuk nanopartikel $\mathrm{Ag}^{0}$. Hal tersebut sesuai dengan penelitian Saputra et al., (2012) dan Senam et al., (2012).

\section{Kemudahan Biodegradasi Selulosa Bakteri dan Kompositnya}

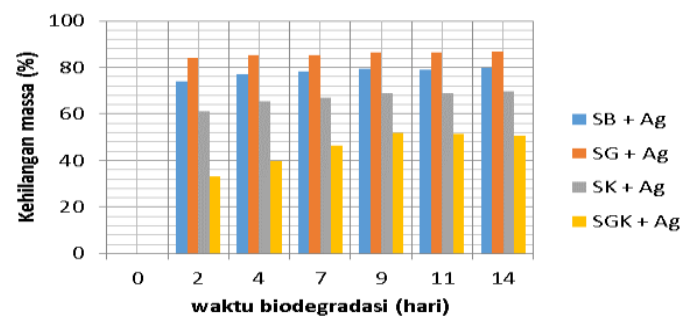

Gambar 2. Grafik kehilangan massa selulosa dan kompositnya terhadap waktu biodegradasi

Berdasarkan Gambar 2, terlihat bahwa untuk semua sampel mengalami kenaikan kehilangan massa seiring dengan bertambahnya waktu biodegradasi.

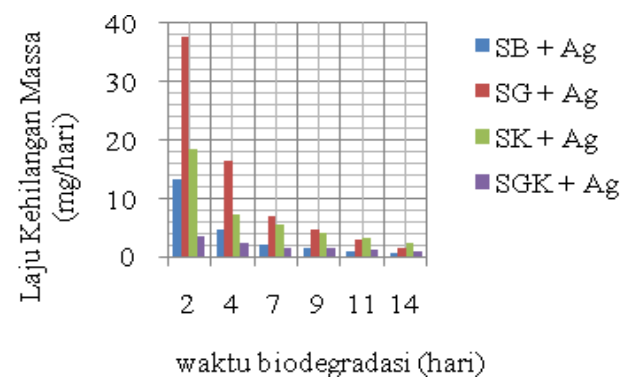

Gambar 3. Laju kehilangan massa selulosa dan kompositnya terhadap waktu biodegradasi

Gambar 3 menunjukkan bahwa untuk semua sampel, laju kehilangan massa menurun dengan bertambahnya waktu biodegradasi. Laju biodegradasi tertinggi terjadi pada hari kedua. Hal ini dapat terjadi karena pada hari kedua, sampel masih mengandung gugus fungsi sebagai sumber nutrisi bagi mikroorganisme dalam tanah. Semakin lama, laju kehilangan massa semakin rendah/turun. Penurunan ini dapat terjadi karena semakin lama, gugus-gugus yang tersedia semakin sedikit (Flieger et al., 2003).

Berdasarkan data kehilangan massa, sampel yang mengalami kehilangan massa tertinggi adalah sampel SG + Ag. Hal tersebut dapat disebabkan karena adanya gliserol dapat merenggangkan ikatan (menurunkan ikatan), $\mathrm{OH}$ gliserol tidak berinteraksi dengan gugus $\mathrm{OH}$ dari selulosa. Perenggangan ikatan ini memudahkan penyerangan oleh bakteri. Berbeda dengan $\mathrm{SG}+\mathrm{Ag}$, gugus $-\mathrm{OH}$ gliserol dalam SGK + Ag mengalami interaksi dengan gugus $-\mathrm{OH}$ selulosa dan dengan $-\mathrm{OH},-\mathrm{NH}_{2}$ kitosan. Adanya interaksi ini menghasilkan ikatan lebih kuat sehingga lebih sulit terurai. Sampel yang paling sulit terdegradasi adalah $\mathrm{SK}+$ Ag. Menurut Pardosi (2008), gugus $\mathrm{NH}_{2}$ dari kitosan berinteraksi dengan $-\mathrm{OH}$ selulosa melalui ikatan hidrogen dan dipol-dipol. Hal ini menyebabkan ikatan menjadi kuat dan lebih sulit terurai.

Oleh karena sampel yang paling mudah terbiodegradasi adalah sampel selulosa dengan penambahan gliserol dideposit nanopartikel perak (SG+Ag), maka sampel tersebut dikarakterisasi lebih lanjut, yaitu uji gugus fungsi dan kristalinitas. Laju kehilangan massa tertinggi terjadi pada waktu biodegradasi 2 hari. Dengan demikian, sampel yang diuji gugus fungsi dan kristalinitas adalah sampel $\mathrm{SG}+\mathrm{Ag}$ yang telah dibiodegradasi selama 2 hari. Gambar 4 menunjukkan spektrum FTIR $\mathrm{SG}+\mathrm{Ag}$ sebelum dan sesudah biodegradasi.

Adapun hasil interpretasi spektrum ATR-FTIR dari sampel $\mathrm{SG}+\mathrm{Ag}$ dapat dilihat pada Tabel 2. Secara kualitatif, SG+Ag sebelum dan sesudah biodegradasi menunjukkan gugus fungsi sama, namun intensitas siklik piran mengalami penurunan sesudah biodegradasi.

Adanya penurunan intensitas serapan siklik piran dalam spektrum FTIR, dapat diartikan bahwa pada hari kedua biodegradasi sudah terjadi aktivitas penguraian selulosa oleh bakteri. Selulase merupakan suatu kompleks enzim yang bekerja bersama-sama menghidrolisis selulosa menjadi glukosa. Terdapat paling tidak 3 enzim yang terlibat dalam hidrolisis sempurna selulosa menjadi glukosa, yaitu eksoglukanase (memutus unitunit selobiosa dari ujung nonpereduksi dari rantai selulosa), endoglukanase (memutus ikatan internal selulosa), dan selobiase (memutus secara spesifik unit glukosa dari ujung nonpereduksi dari selo-oligosakarida (Nugraha, 2006; Anindyawati, 2010). 

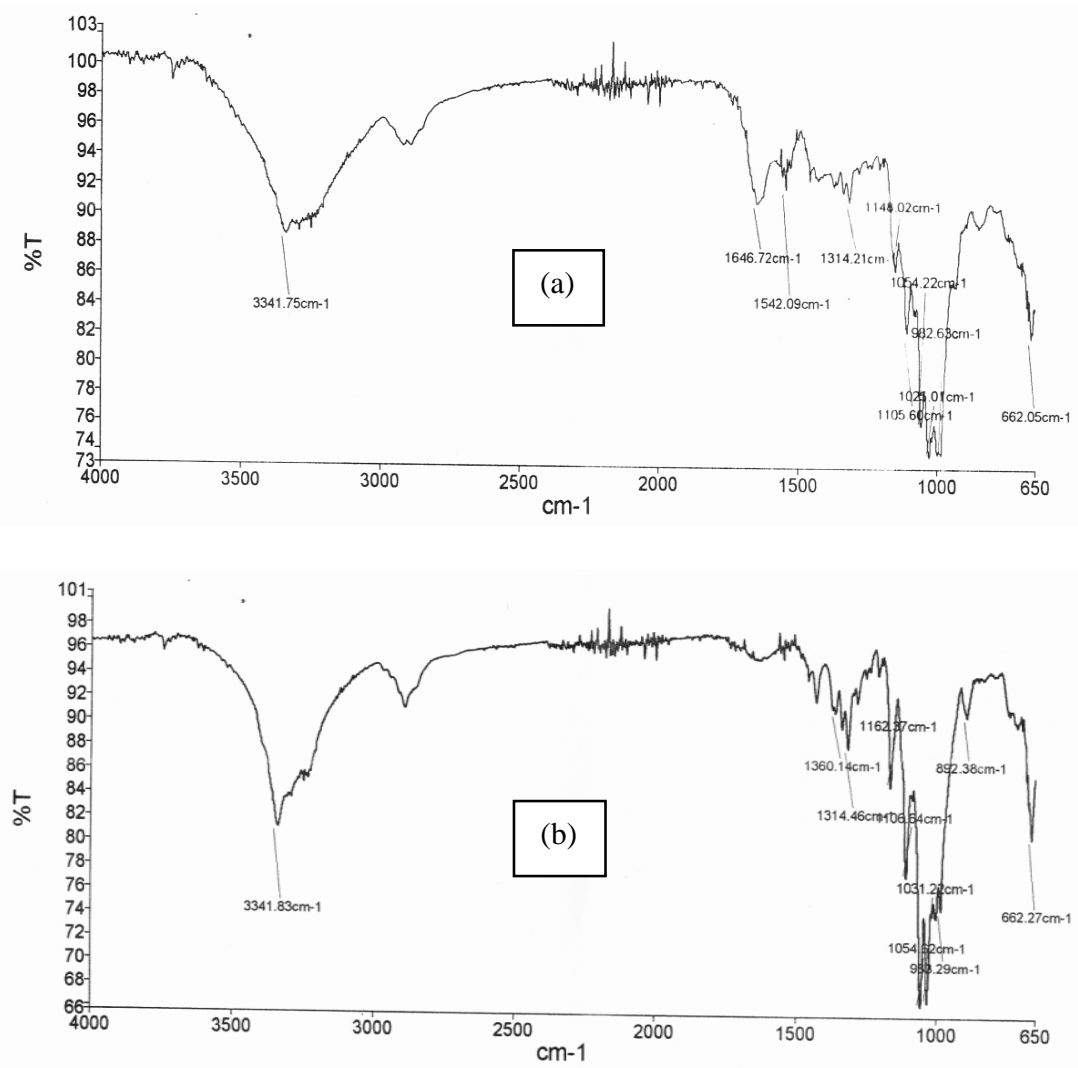

Gambar 4. Spektrum ATR-FTIR sampel SG + Ag sebelum (a) dan sesudah (b) biodegradasi

Tabel 2. Gugus fungsi sampel $\mathrm{SG}+\mathrm{Ag}$ sebelum dan sesudah dibiodegradasi

\begin{tabular}{cccc}
\hline \multicolumn{2}{c}{ Sebelum Biodegradasi } & \multicolumn{2}{c}{ Setelah Biodegradasi } \\
\hline \multirow{2}{*}{ Bil. Gelombang $\left(\mathrm{cm}^{-1}\right)$} & $\begin{array}{c}\text { Jenis Gugus } \\
\text { Fungsi }\end{array}$ & Bilangan Gelombang $\left(\mathrm{cm}^{-1}\right)$ & Jenis Gugus Fungsi \\
\hline 3341.75 & $-\mathrm{OH}$ & 3341.83 & $-\mathrm{OH}$ \\
1646.72 & Siklik piran & 1650.01 & Siklik piran \\
1025.01 & $\mathrm{C}-\mathrm{O}$ & 1031.22 & $\mathrm{C}-\mathrm{O}$ \\
\hline
\end{tabular}

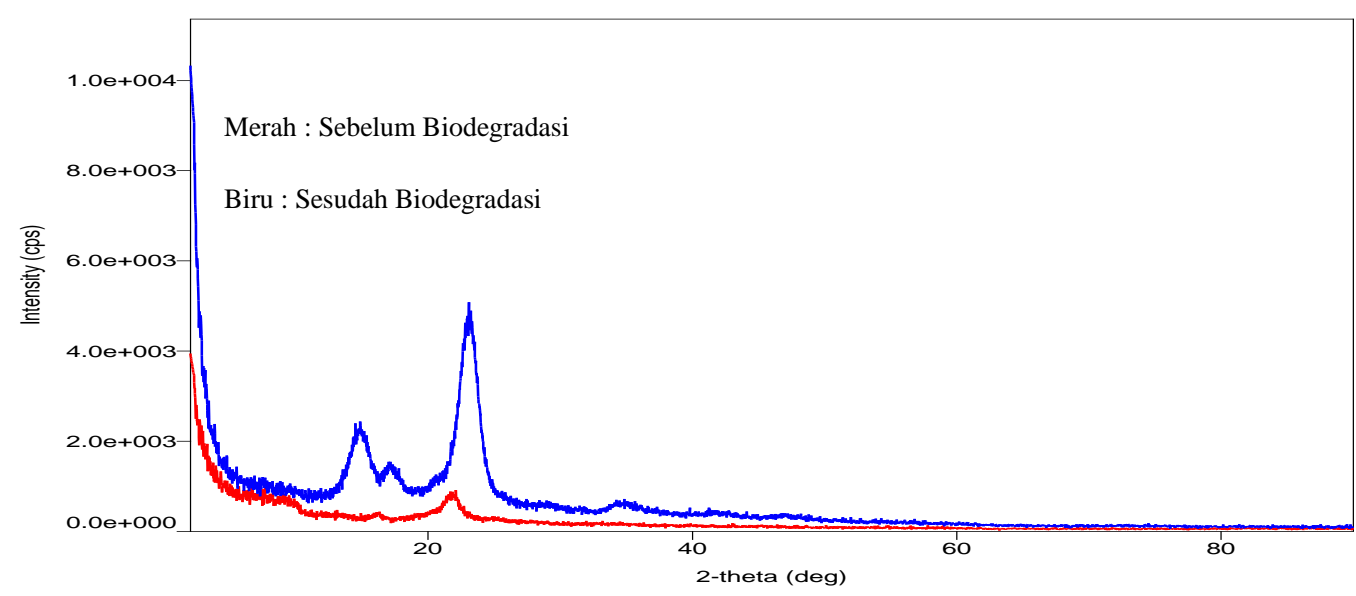

Gambar 5. Difraktogram sinar-X SG + Ag sebelum dan sesudah biodegradasi 
Tahap pertama, enzim endoglukanase menyerang daerah amorf dari selulosa secara acak dan membentuk ujung-ujung nonpereduksi yang memudahkan kerja eksoglukanase. Selanjutnya, enzim eksoglukanase menghidrolisis daerah kristalin dari selulosa dengan membebaskan dua unit glukosa. Sistem kerja kedua enzim ini menghasilkan unit-unit sakarida yang lebih kecil yang selanjutnya dihidrolisis oleh $\beta$ glukosidase menghasilkan glukosa (Nugraha, 2006).

\section{Kristalinitas SG+Ag}

Gambar 5 menunjukkan terdapat 4 puncak di daerah $2 \theta$ yaitu $8.14^{\circ} ; 14.79^{\circ}$; $20.08^{\circ}$; dan $20.60^{\circ}$ pada difraktogram sampel $\mathrm{SG}+\mathrm{Ag}$ sebelum dibiodegradasi. Berdasarkan keempat puncak tersebut, puncak yang paling kuat terdapat di daerah $20.60^{\circ}$. Sampel SG + $\mathrm{Ag}$ setelah dibiodegradasi selama 2 hari memiliki 5 puncak yaitu di daerah $2 \theta 14.69^{\circ}$; $17.12^{\circ} ; 23.093^{\circ} ; 34.89^{\circ}$; dan $47.8^{\circ}$ dengan puncak paling tajam ditunjukkan pada peak di daerah $2 \theta 23.093^{\circ}$.

Kedua difraktogram memiliki puncak di daerah yang hampir sama, yaitu di daerah $2 \theta$ $20^{\circ}-40^{\circ}$. Puncak yang paling banyak ditemui dalam selulosa bakteri berada pada daerah $2 \theta$ $20^{\circ}-40^{\circ}$ dengan puncak di daerah $2 \theta 22^{\circ}$ yang menjadi ciri dari nata de leri (Agustri, 2012). Pernyataan ini sesuai dengan kedua difraktogram sampel yang memiliki puncak di daerah $2 \theta 20^{\circ}-40^{\circ}$. Adanya puncak sebagai ciri dari nata de leri pada daerah $2 \theta 22^{\circ}$ juga sesuai dengan hasil difraktogram meskipun tidak tepat $22^{\circ}$, yaitu $20.60^{\circ}$ dan $23.093^{\circ}$. Hal ini menunjukkan bahwa material merupakan selulosa bakteri. Kedua sampel (sebelum dan sesudah biodegradasi) sama-sama ditambah dengan gliserol, maka perbedaan kedua difraktogram tidak dipengaruhi oleh faktor gliserol. Penelitian Christy dan Umadevi (2012), menunjukkan bahwa nanopartikel perak menghasilkan puncak difraksi di daerah $2 \theta \quad 37.85^{\circ} ; \quad 44.0^{\circ} ; \quad 64.2^{\circ} ;$ dan $77.2^{\circ}$. Difraktogram pertama tidak menunjukkan adanya peak di daerah tersebut, sedangkan difraktogram kedua menujukkan terdapat serapan di daerah $34.89^{\circ}$ dan $47.8^{\circ}$. Hal ini menunjukkan bahwa koloid nanopartikel terdeposit di daerah amorf sehingga nanopartikel perak dapat terdeteksi setelah dilakukan biodegradasi (bagian amorf diserang oleh bakteri).
Puncak-puncak pada difraktogram sampel setelah terbiodegradasi lebih tinggi dan lebih tajam daripada puncak-puncak pada difraktogram sampel sebelum terbiodegradasi. Dengan demikian, $\mathrm{SG}+\mathrm{Ag}$ setelah terbiodegradasi bersifat lebih kristalin daripada sampel sebelum terbiodegradasi. Hal ini diperkuat oleh derajat kristalinitas dari masingmasing material. $\mathrm{SG}+\mathrm{Ag}$ sebelum dibiodegradasi memiliki derajat kristalinitas $17.06 \%$, sedangkan setelah dibiodegradasi memiliki derajat kristalinitas sebesar $39.77 \%$. Dengan demikian, proses biodegradasi dapat meningkatkan kristalinitas sampel SG + Ag.

Enzim endoglukanase pada tahap pertama penguraian selulosa terutama menyerang daerah amorf dari selulosa secara acak dan membentuk ujung-ujung nonpereduksi (Nugraha, 2006; Khairiah et al., 2013). Oleh karena itu, sampel yang pada awalnya memiliki daerah-daerah amorf dan kristalin yang bercampur, bagian amorf akan diserang oleh bakteri sehingga daerah amorf akan berkurang dan derajat kristalinitas meningkat.

\section{SIMPULAN}

Penambahan gliserol pada preparasi selulosa bakteri dapat meningkatkan kemudahan biodegradasi, sedangkan penambahan kitosan dapat menurunkan kemudahan biodegradasi. Semakin lama biodegradasi, kehilangan massa semakin meningkat sedangkan laju kehilangan massa semakin menurun. Sesudah biodegradasi, Selulosa-Gliserol dideposit nanopartikel perak $(\mathrm{SG}+\mathrm{Ag})$ mengalami penghilangan siklik piran dan peningkatan kristalinitas.

\section{UCAPAN TERIMAKASIH}

Terimakasih disampaikan kepada Kementerian Negara Riset dan Teknologi atas bantuan dana melalui INSinas 2014.

\section{DAFTAR PUSTAKA}

Agustri AA. 2012. Preparasi dan karakterisasi bioplastik dari air cucian beras dengan penambahan kitosan. Skripsi, Universitas Negeri Yogyakarta.

Anindyawati T. 2010. Potensi selulase dalam mendegradasi lignoselulosa limbah 
pertanian untuk pupuk organik. Berita Selulosa. 45(2): 70-77.

Bielecki S. 2002. Bacterial Cellulose. Biopolymers: Polysaccharides. 5(1): 37-90.

Chawla PR, Bajaj IB, Survase SA, Singhal RD. 2009. Microbial Cellulose: fermentative Production and Applications. Biotechnol. 47 (2): 107-124.

Christy AJ, Umadevi M. 2012. Synthesis and Characterization of Monodispersed Silver Nanoparticles. M. IOP Publishing. Adv. Nat. Sci.: Nanosci. Nanotechnol. 3

Chulifah U. 2010. Biodegradasi bioplastik nata de leri menggunakan lumpur aktif. Laporan Penelitian. Universitas Negeri Yogyakarta.

Flieger M, Kantrova A, Prell T. 2003. Biodegradable plastics from renewable sources. Journal of Folia Microbiologics. 48: 22-44.

Handiyanto S, Hastuti US, Prabaningtyas S. 2012. Kajian penggunaan air cucian beras sebagai bahan media pertumbuhan biakan murni jamur tiram putih (Pleurotusostreatus var. Florida). Laporan Penelitian. Universitas Negeri Malang.

Khairiah E, Khotimah S, Mulyadi A. 2013. Karakterisasi dan kepadatan bakteri pendegradasi selulosa pada tanah gambut di desa parit banjar kabupaten Pontianak. Jurnal Protobiont. 2(2): 87-92.

Mutia T, Eriningsih R, Safitri R. 2011. Membran alginat sebagai pembalut luka primer dan media penyampaian obat topikal untuk luka yang terinfeksi. Jurnal Riset Industri. V(2): 161-174.

Nugraha R. 2006. Produksi enzim selulase oleh Penicillium nalgiovense SS240 pada Substrat Tandan Sawit. Skripsi, Institut Pertanian Bogor.

Pardosi D. 2008. Pembuatan material selulosa bakteri dalam medium air kelapa melalui penambahan sukrosa, kitosan, dan gliserol menggunakan Acetobacter xylinum. Tesis, Universitas Sumatera Utara.

Prabhu S, Poulose EK. 2012. Silver Nanoparticles: mechanism of antimicrobial action. synthesis, medical applications, and toxicity effects. International Nano Letters Springer Open Journal. 2(32): 1-10.
Rohaeti E, Widjajanti E, LFX, Rachmawati E. 2014. Silver nanoparticle impregnated on the composite of bacterial cellulosechitosan-gliycerol as antibacterial material. Proceeding of International Conference On Research Implementation and Education of Mathematic and Sciences. C-6: 43-53.

Rohaeti E, Pratomo H. 2011. Bioplastik nata de casava sebagai bahan edible film ramah lingkungan. Jurnal Penelitian Saintek. 16(2): 172-190.

Rohaeti E, Rahayu T. 2012. Pengembangan biomaterial selulosa bakteri dari limbah rumah tangga dengan penambahan kitosan dan pemlastis sebagai material penutup luka. Laporan Penelitian. Universitas Negeri Yogyakarta.

Rohaeti E. 2009. Karakterisasi biodegradasi polimer. Prosiding Seminar Nasional Penelitian, Pendidikan, dan Penerapan MIPA.

Sanjaya I, GMH, Puspita T. 2010. Pengaruh penambahan gliserol khitosan dan plasticizer gliserol pada karakteristik plastik biodegradable dari pati limbah singkong. Laporan Penelitian. Institut Teknologi Surabaya.

Saputra AH, Haryono A, Laksmono JA, Anshari MH. 2011. Preparasi koloid nanosilver dengan berbagai jenis reduktor sebagai bahan anti bakteri. Jurnal Sains Materi Indonesia. 12(3): 202-208.

Senam, Rohaeti E, Sutrisno H, Rakhmawati A. 2012. Aplikasi nanopartikel perak pada komposit selulosa-bakteri kitosan sebagai antibakteri untuk keperluan biomedis. Laporan Penelitian. Universitas Negeri Yogyakarta.

Susakti A. 2014. Tingginya Konsumsi Beras di Indonesia. Diakses dari "http://bbp2tp.litbang.pertanian.go.id" pada tanggal 7 November 2014 pukul 20.49 WIB.

Tareq A, Alam M, Raza S, Sarvar T, Fardous Z, Chowdhury AZ, Hossain S. 2013. Comparative study of antibacterial activity of chitin and chemically treated chitosan prepared from shrimp (Macrobrachium Rosenbergii) shell waste. Journal of Virology and Microbiology. 1-9.

Torres FG, Commeaux S, Troncoso OP. 2012. Biocompatibility of bacterial cellulose based 
biomaterial. Journal of Finctional Biomaterials. 3: 864-878.

Wardhani RAK, Rudyardjo DI, Supardi A. 2014. sintesis dan karakterisasi bioselulosa-kitosan dengan penambahan gliserol sebagai
Plasticizer. Laporan Penelitian. Universitas Airlangga.

Zhang S, Luo J. 2011. Preparation and properties of bacterial cellulose/alginate blend biofibers. Journal of Engineered Fibers and Fabrics. 6(3): 69-73. 